\title{
AKURASI
}

\section{TRACER STUDY LULUSAN MAGISTER AKUNTANSI UNTUK PENGEMBANGAN KURIKULUM YANG ADAPTIF DENGAN KEBUTUHAN DUNIA KERJA}

\author{
Akram $^{1}$, Lilik Handajani ${ }^{2}$, Lalu Takdir Jumaidi ${ }^{3}$ \\ Fakultas Ekonomi dan Bisnis, Universitas Mataram \\ ${ }^{2}$ Corresponding author: lilikhandajani@unram.ac.id
}

\begin{tabular}{l}
\hline INFORMASI ARTIKEL \\
\hline Article history: \\
Dikirim tanggal: $25 / 11 / 2020$ \\
Revisi pertama tanggal: $1 / 12 / 2020$ \\
Diterima tanggal: $10 / 12 / 2020$ \\
Tersedia online tanggal: $24 / 12 / 2020$
\end{tabular}

Tersedia online tanggal: 24/12/2020

\begin{abstract}
ABSTRAK
Tujuan dari tracer study ini untuk mengetahui outcome dan output lulusan, serta proses pembelajaran dan penilaian stakeholder pengguna lulusan terhadap kinerja lulusan. Untuk menggali informasi dari lulusan dan pengguna, kuisioner online didistribusikan kepada lulusan yang telah menyelesaikan studi pada tahun 2018 dan 2019 pada Program Studi Magister Akuntansi Universitas Mataram. Hasil tracer study berhasil memberikan data kuantitatif dan deskriptif mengenai outcome dan output lulusan serta evaluasi proses pembelajaran. Penilaian dari stakeholder pengguna lulusan menyatakan bahwa kompetensi yang dimiliki oleh lulusan sesuai dengan yang diharapkan, terutama berkaitan dengan integritas etika dan moral, keahlian bidang ilmu, penguasaan penggunaan teknologi informasi, kepemimpinan, kerjasama tim serta kemampuan berkomunikasi. Tracer study penting dilakukan secara periodik untuk peningkatan pengelolaan proses akademik, pembelajaran dan evaluasi kurikulum secara berkala sehingga dapat meningkatkan kompetensi lulusan sesuai kebutuhan pasar kerja serta memenuhi harapan dari stakeholders pengguna lulusan.
\end{abstract}

Kata kunci: tracer study, lulusan, outcome, output, proses pembelajaran.

\begin{abstract}
The purpose of this tracer study is to determine the outcome and output of graduates, as well as the learning process and assessment of stakeholders on graduate performance. To gather information from graduates and users, online questionnaires were distributed to 105 graduates who had completed their studies in 2018 and 2019 at the Mataram University Master of Accounting Study Program. The results of the tracer study succeeded in providing quantitative and descriptive data regarding the outcomes and outputs of graduates as well as evaluation of the learning process. The assessment of stakeholders states that the competencies possessed by graduates are as expected, especially with regard to ethical and moral integrity, scientific expertise, mastery of the use of information technology, leadership, teamwork and communication skills. It is important that tracer studies be carried out periodically to improve the management of the academic process, periodic learning and curriculum evaluation so that it can increase the competence of graduates according to the needs of the job market and meet the expectations of stakeholders.
\end{abstract}

Key words: tracer study, graduates, outcome, output, learning process. 


\section{Pendahuluan}

Kualitas program studi salah satu indikatornya ditentukan oleh daya serap lulusan pada dunia kerja karena kesesuaian kompetensi yang dimiliki lulusan. Kesesuaian pengetahuan, kemampuan dan ketrampilan yang dimiliki lulusan serta kemampuan profesional dan pengembangan diri menjadi tolok ukur penting keberhasilan lulusan dalam memenuhi harapan pengguna lulusan dan kebutuhan pasar kerja. Indikator keberhasilan program studi dalam menjalankan proses akademik bagi mahasiswa yang dididiknya dapat diketahui dari kesesuaian kurikulum dengan kebutuhan pengguna, kompetensi lulusan yang dimiliki lulusan dan daya serap lulusan dalam pasar kerja, pengembangan karir profesional dan penerimaan lulusan dalam kehidupan masyarakat umumnya (Handajani, Alamsyah \& Widiastuty, 2015). Untuk tujuan tersebut, Program studi perlu melakukan kegiatan pelacakan lulusan atau yang disebut juga sebagai tracer study.

Studi pelacakan alumni atau yang lebih dikenal sebagai tracer study berperan penting dalam pengelolaan proses pembelajaran dan pengembangan kualitas akademik. Melalui umpan balik (feedback) yang diberikan lulusan kepada program studi akan dapat memberikan manfaat dan dipergunakan untuk evaluasi proses akademik yang dijalankan serta perbaikan kurikulum secara berkala. Dengan demikian program studi dapat melakukan perbaikan dan peningkatan pengetahuan dan ketrampilan yang dibutuhkan sesuai dengan harapan pengguna lulusan seiring perkembangan dan perubahan teknologi, sosial, dan kelembagaan (Indriasari, 2012). Sejalan dengan manfaat tracer study yang dikemukakan sebelumnya, umpan balik yang diperoleh dari alumni ini dibutuhkan oleh perguruan tinggi dalam usahanya untuk perbaikan serta pengembangan kualitas dan sistem pendidikan serta untuk memetakan dunia usaha dan industri agar jeda diantara kompetensi yang diperoleh alumni saat kuliah dengan tuntutan dunia kerja dapat diperkecil (ITB Career Center, 2018).

Pelacakan lulusan bertujuan untuk memberikan informasi mengenai bidang pekerjaan lulusan setelah menyelesaikan studinya, karakteristik yang dibutuhkan dalam transisi dari kuliah menuju dunia kerja, kondisi pekerjaan saat ini, kesesuaian pengetahuan, ketrampilan dan kompetensi lulusan dengan harapan stakeholder pengguna lulusan dan kebutuhan pasar kerja, waktu tunggu lulusan sampai memperoleh pekerjaan, pendapatan yang diperoleh pertama, serta upaya peningkatan kualitas diri lulusan setelah bekerja menjadi poin-poin penting dalam tracer studi (Lange, 2001; Heidemann, 2011; Setyorini et al., 2012). Sejalan dengan argumentasi sebelumnya, Karyono dan Hermanto (2013) menyatakan bahwa evaluasi capaian kompetensi dan keunggulan suatu program studi, evaluasi kurikulum secara berkelanjutan dan pengembangan akademik serta kepentingankepentingan akreditasi merupakan manfaat yang diperoleh dengan dilaksanakan kegiatan tracer study.

Program Studi Magister Akuntansi Fakultas Ekonomi dan Bisnis Universitas Mataram yang berdiri sejak tahun 2007 telah menghasilkan banyak lulusan yang telah bekerja pada berbagai sektor pemerintah dan swasta maupun berwirausaha serta berbagai bidang pekerjaan lainnya. Tracer study pertama dilakukan pada tahun 2015 (Handajani et al., 2015) dan kegiatan tracer study selanjutnya telah dilakukan pada tahun 2018 (Herwanti, Handajani, Hermanto \& Irwan, 2018). Hasil tracer study pada tahun 2015 telah mampu mengidentifikasi karakteristik lulusan dan kompetensi yang dimiliki lulusan meskipun 
respon yang diperoleh relatif masih rendah. Namun demikian hasil tracer study tersebut mampu memberikan data dan informasi lulusan tahun 2011-2015 yang terkait dengan demografi lulusan, pekerjaan, kompetensi yang dimiliki serta kesesuaian kompetensi yang dimiliki dengan kebutuhan dunia kerja dan harapan stakehoder. Hasil tracer study Program Magister Akuntansi pada tahun 2018 menjelaskan bahwa sebagian besar lulusan telah terserap oleh pasar kerja terutama pada sektor pemerintahan (78\%) dan sektor swasta (22\%). Kesesuaian pengetahuan akuntansi, prestasi akademik (IPK) dan penguasaan bahasa Inggris merupakan kompetensi utama yang harus dimiliki lulusan, selain faktor penunjang lainnya penguasaan teknologi Informasi, kemampuan manajerial dan komunikasi sesuai kebutuhan dunia kerja dan harapan stakeholder pengguna lulusan.

Adanya pemetaan dan database lulusan terkini yang akurat sangat diperlukan untuk mengevaluasi keberhasilan proses akademik dan kurikulum yang digunakan serta kesesuaian kompetensi lulusan dengan kebutuhan dunia kerja. Oleh karena itu kegiatan pelacakan alumni pada Program Studi Magister Akuntansi Universitas Mataram perlu dilakukan untuk dapat melakukan pemuktakhiran data lulusan melalui kegiatan tracer study dengan perbaikan metode tracer study yang dapat meningkatkan respon rate. Kegiatan pelacakan lulusan dilakukan melalui beberapa tahapan. Pertama, pengumpulan data lulusan dari bagian akademik Program Studi Magister Akuntansi untuk mengidentifikasi tahun kelulusan seperti alamat email lulusan, maupun jejaring komunikasi lainnya seperti nomor kontak lulusan dan jaringan komunikasi kelompok. Kedua, perumusan instrumen pengumpulan data lulusan dalam bentuk kuisioner tracer study yang mengkombinasikan bentuk kuisioner menggunakan kuisioner elektronik, kuisioner dalam bentuk paper yang dikirim melalui email. Ketiga, memilih metode tracer study yang digunakan untuk penyebaran kuisioner. Hal ini karena penyebaran kuisioner kepada lulusan memiliki konsekuensi yang jika dilakukan melalui pos, wawancara, telepon membutuhkan waktu dan biaya yang cukup besar karena domisili lulusan yang telah menyebar ke luar daerah atau luar pulau (Karyono dan Hermanto, 2013).

Program Studi Magister Akuntansi kegiatan tracer study telah dilakukan selama 2 (dua) kali yaitu pada tahun 2015 dan tahun 2018. Kegiatan tracer study yang dilakukan pada tahun-tahun sebelumnya tersebut memiliki beberapa keterbatasan, seperti tingkat respon rate yang masih dibawah $50 \%$, penggunaan media penyebarluasan kuisioner yang terbatas hanya menggunakan email lulusan, nomor telepon dan pengiriman kuisioner langsung serta konten kusioner yang relatif terbatas. Kegiatan tracer study pada tahun 2020 ini dilakukan dengan memperbaiki keterbatasan dalam metode sebelumnya sehingga dilakukan dengan pendekatan metode pelaksanaan yang lebih tepat. Dengan keterbatasanketerbatasan yang ada dalam melaksanakan kegiatan tracer study sebelumnya tersebut, maka kegiatan tracer study ini akan mengadopsi pendekatan yang paling efektif dan efisien dengan menyebarkan kuisioner online dengan memanfaatkan jejaring komunikasi media sosial antar alumni. Tujuan dari penelitian tracer study ini adalah untuk mengidentifikasi dan mendeskripsikan outcome lulusan dalam transisi dari dunia pendidikan tinggi ke dunia kerja, kesesuaian output yang dimiliki lulusan dengan kompetensi yang diperlukan di dunia kerja dan mengevaluasi proses pembelajaran. Tracer study ini juga menggali data dari pengguna lulusan untuk memperoleh informasi tentang tingkat kepuasan pengguna terhadap keahlian dan pengetahuan serta kompetensi yang dimiliki oleh lulusan. 
Informasi yang terkini dan akurat mengenai data lulusan umpan balik lulusan tentang outcome, output, proses pembelajaran dari hasil pelacakan alumni menjadi masukan dan pertimbangan untuk melakukan evaluasi kurikulum dan proses akademik, termasuk fasilitas dan layanan akademik serta pertimbangan untuk menentukan kebijakan yang tepat dalam meningkatkan kompetensi dan kualitas lulusan sesuai dengan kebutuhan dunia kerja. Dengan demikian hasil dari tracer study ini dapat memberikan kontribusi data terkini dan akurat tentang profil lulusan, aspek profesionalisme dan kesesuaian kompetensi yang dimiliki lulusan dan kemampuan adaptif lulusan dalam menghadapi dan beradaptasi dengan kebutuhan dunia kerja.

\section{Kerangka Teoretis dan Kerangka Pikir Penelitian}

Proses pendidikan yang bermutu akan dapat menghasilkan lulusan yang dibutuhkan oleh pengguna, dan untuk mencapai tujuan tersebut program studi harus dapat mengetahui keinginan dan harapan pengguna dengan melibatkan alumni sebagai sumber informasi (Nursubiyantoro dan Puryani, 2016). Untuk mengevaluasi kinerja prodi dibutuhkan sistem informasi yang mendukung penyimpanan data para alumninya, data tahun kelulusan, tempat bekerja, kesesuaian kerja dan waktu tunggu dalam memperoleh pekerjaan (Rachmatullah dan Gunawan, 2016). Tracer study digunakan sebagai pendekatan untuk mendapatkan informasi yang penting dari lulusan untuk dapat meningkatkan kualitas proses pembelajaran pada program studi. Subtansi penting dalam tracer study adalah untuk memperoleh umpan balik (feedback) dari para lulusan tentang relevansi proses pendidikan yang telah dijalani dengan kemampuan meningkatkan taraf hidup lulusan di masyarakat (Diana dan As'ad, 2017).

Penelitian sebelumnya tentang tracer study telah banyak dilakukan pada banyak Perguruan Tinggi sebagai suatu kebutuhan. Tujuan dari tracer study adalah memperoleh umpan balik (feed back) dari lulusan sehingga program studi dapat melakukan perbaikan dan pengembangan kualitas sistem pembelajaran dan kualitas pengelolaan program studi. Tujuan dari tracer study ini juga dapat memberikan pemetaan antara kebutuhan dunia kerja/dunia usaha /industri dengan kompetensi yang dimiliki lulusan sehingga dapat memperkecil kesenjangan (gap) antara kemampuan dan kompetensi yang dimiliki lulusan yang diperoleh selama studi dengan tuntutan dunia kerja.

Nuryake et al. (2015) menyatakan bahwa penelitian tracer study bertujuan untuk memperoleh gambaran lama masa tunggu alumni sampai mendapatkan pekerjaan, mendeskripsikan penilaian alumni mengenai penyelenggaraan dan mutu layanan program dan mendeskripsikan penilaian pengguna alumni terhadap kompetensi lulusan. Pelacakan alumni dapat memberikan manfaat bagi institusi maupun dunia kerja. Melalui tracer study akan dapat diketahui kinerja lulusan dengan menganalisis data lulusan untuk mengukur relevansi kompetensi yang dimiliki lulusan dengan kebutuhan dunia kerja (Diana dan As'ad, 2017). Manfaat tracer study tidak terbatas pada perguruan tinggi saja, tetapi lebih jauh lagi dapat memberikan informasi penting mengenai hubungan antara dunia pendidikan tinggi dengan dunia usaha dan industri (ITB Career Center, 2018). Lebih lanjut dinyatakan bahwa tracer study dapat menyajikan informasi mendalam dan rinci mengenai kecocokan kerja baik horisontal maupun vertikal sehingga dapat membantu mengatasi permasalahan kesenjangan kesempatan kerja dan upaya perbaikannya. 
Beragam pendekatan dilakukan dalam melakukan tracer study baik secara manual dan online. Sistem manual memiliki keterbatasan karena membutuhkan waktu yang lama dan biaya yang besar serta kemungkinan kehilangan dan kerusakan data. Untuk memenuhi kendala dalam memperoleh data dari alumni dibutuhkan sebuah sistem informasi tracer study. Pelacakan alumni secara online memberikan banyak kemudahan dalam pelaksanaan tracer study. Rahmatullah dan Gunawan (2016) menyatakan bahwa diperlukan suatu sistem informasi yang dapat mendukung penyimpanan data para alumni, data tahun kelulusan, tempat bekerja dan kesesuaian kerja serta waktu tunggu dalam memperoleh pekerjaan. Syam dan Manga (2017) mengenalkan data kuisioner alumni menggunakan sistem yang berbasis website melalui data warehouse dan penerapan metode Online Analitycal Processing (OLAP) yang nantinya akan berfungsi sebagai laporan dari data alumni dalam bentuk grafik sehingga akan memberikan kemudahan staf kemahasiswaan dan alumni dalam melakukan inputan karena bisa dilakukan dimanapun dengan adanya koneksi internet. Hal ini sejalan dengan argumentasi Renny et al. (2013) bahwa pelaksanaan tracer study harus difasilitasi oleh layanan teknologi untuk optimalisasi penggunaan tracer study melalui website career center. Sejalan dengan metode tracer study sebelumnya, pelaksanaan tracer study dengan menggunakan portal jaringan media sosial dapat menjadi salah satu media alternatif untuk menarik minat lulusan berinteraksi dengan media tersebut sehingga pengumpulan data alumni menjadi lebih optimal (Marisa, Efendi dan Mumpuni, 2016). Suryani dan Khairuddin (2017) menyatakan bahwa adanya sistem pelacakan alumni secara online maka setiap saat alumni dan pengguna dapat mengisi data yang dibutuhkan oleh institusi sehingga memudahkan untuk evaluasi dan re-akreditasi di setiap prodi.

Lange (2001) mengidentifikasi indikator-indikator kunci pelacakan alumni seperti kemampuan adaptasi dan transisi lulusan ke dunia kerja, relevansi kompetensi lulusan dengan kebutuhan pasar kerja dan mampu memenuhi harapan atau kriteria yang dibutuhkan oleh pengguna lulusan. Lebih lanjut dinyatakan dalam Lange (200) faktorfaktor lainnya yang menjadi indikator kunci adalah pertumbuhan pasar tenaga kerja yang potensial serta dampak positif kompetensi lulusan terhadap aspek sosial dan ekonomi berkaitan dengan penerimaannya di masyarakat. Tracer study adalah rekam jejak alumni setelah lulus dari program studi pada suatu Perguruan Tinggi.

Program Studi melaksanakan Tracer Study karena membutuhkan umpan balik dari alumni untuk mengetahui outcome, output dan input serta proses pendidikan dalam usahanya untuk melakukan evaluasi dan perbaikan proses pembelajaran dan peningkatan kompetensi lulusan. Outcome pendidikan adalah bentuk transisi dari dunia pendidikan tinggi ke dunia kerja dan masyarakat. Output pendidikan yaitu penilaian diri oleh lulusan terhadap penguasaan dan pemerolehan kompetensi, pengetahuan, ketrampilan, motivasi maupun penilaian. Proses pembelajaran berupa evaluasi proses pembelajaran dan kontribusi pendidikan tinggi terhadap pemerolehan kompetensi. Input pendidikan berkaitan dengan upaya penggalian lebih lanjut terhadap informasi sosiobiografis lulusan. Merujuk pada Schomburg (2011), gambar 1 berikut ini menjelaskan hubungan antara input, output, proses pembelajaran dan outcome dalam suatu kegiatan tracer study. 


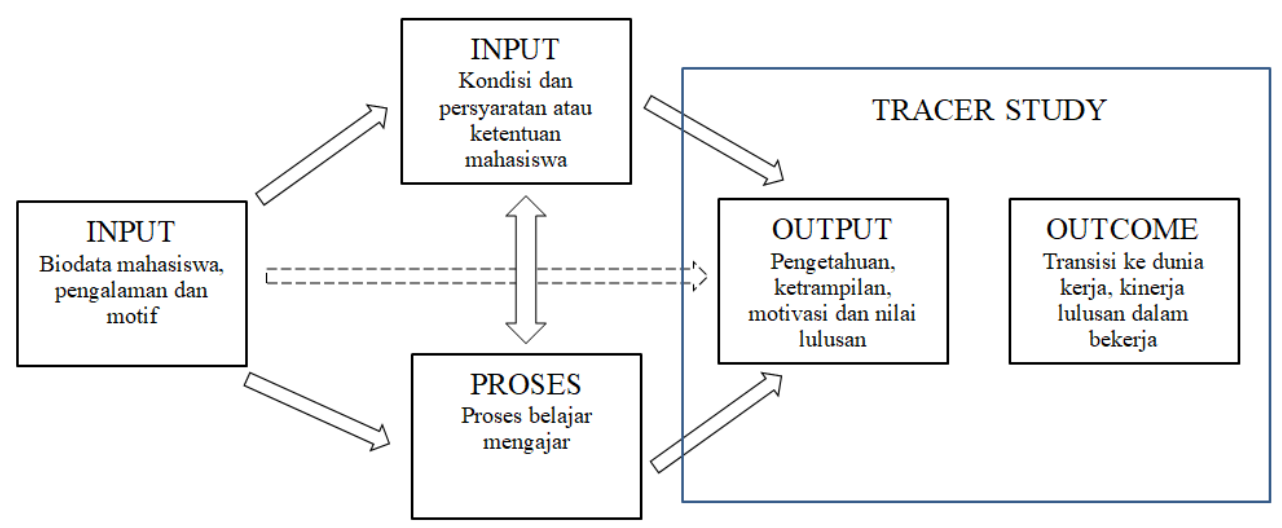

Gambar 1. Kegiatan Tracer Study

\section{Metode Penelitian}

Penelitian tentang tracer study ini merupakan jenis penelitian deskriptif kuantitatif melalui pendekatan survei yang dilakukan melalui beberapa tahapan sebagai berikut: (1) pengembangan instrumen kuisioner online; (2) identifikasi kontak data alumni yang aktif, (3) penyebaran kuisioner dan pengumpulan data serta (4) analisis data dan pelaporan. Metode penyampelan dilakukan dengan cara stratified random sampling secara proporsional sesuai dengan jumlah lulusan dan tahun lulus. Jenis data yang dikumpulkan dalam penelitian ini adalah data primer yang diperoleh langsung dari lulusan melalui kuesioner yang dibuat terstruktur. Penyebaran kuesioner dilakukan secara online melalui kuisioner elektronik, platform jaringan komunikasi melalui media sosial dan email lulusan.

Analisis data kuantitatif digunakan untuk mengevaluasi tingkat tanggapan terhadap kuisioner, jika dipandang tingkat tanggapan masih rendah dilakukan upaya-upaya proaktif untuk meningkatkan response rate. Tabulasi hasil kuisioner dilakukan untuk analisis data hasil kuisioner. Selanjutnya dilakukan verifikasi temuan dengan indikator kunci yang relevan. Pada tahap akhir dibuat database informasi lulusan sebagai dasar untuk memberikan rekomendasi, mengevaluasi proses akademik dan perbaikan dalam perbaikan kurikulum pada program studi.

\section{Hasil dan Pembahasan}

Tracer study ini dilakukan terhadap lulusan yang telah menyelesaikan studi pada dua tahun terakhir yaitu pada tahun 2018 dan 2019, dengan menggunakan instrumen yang dikembangkan dari pedoman penilaian akreditasi program studi magister. Tracer study ini disebarkan melalui instrumen kuisioner online memuat pertanyaan-pertanyaaan yang harus diisi oleh responden lulusan dengan cara menjawab pertanyaan mengenai outcome, output dan proses pembelajaran. Tracer study ini juga memuat pertanyaan untuk responden pengguna lulusan terhadap kepuasan pengguna terhadap kompetensi yang dimiliki lulusan. Jumlah lulusan yang ditracer adalah sebanyak 105 yaitu alumni yang menyelesaikan studinya pada tahun 2018 dan 2019. Jumlah lulusan tahun 2018 yang ditracer adalah sebanyak 91 orang, sedangkan jumlah lulusan pada tahun 2019 yang ditracer adalah sebanyak 14 orang. Dari 105 kuisioner yang didistribusikan, responden yang mengisi sebanyak 80 orang. Dengan demikian tingkat tanggapan (response rate) penelitian tracer 
study ini adalah 76,19\%. Dari 80 responden yang mengisi kuisioner online mayoritas bekerja sebagai Pegawai Negeri Sipil (PNS) dan karyawan yaitu sebesar 75 orang atau $94 \%$, sedangkan sisanya $6 \%$ responden adalah lulusan yang bekerja sebagai wirausaha. Hal ini berarti sebagian besar lulusan Program Studi Magister Akuntansi telah terserap pada pasar kerja dan memiliki pekerjaan. Berdasarkan hasil tracer study rata-rata masa studi lulusan adalah 2,4 tahun dengan IPK rata-rata sebesar 3,7 dalam skala 4.

Indikator yang berkaitan dengan outcome lulusan disajikan pada tabel 1. Masa tunggu lulusan untuk memperoleh kerja kurang dari 1 tahun adalah tertinggi sebesar 64\% yang berarti bahwa lulusan telah terserap pasar kerja tidak lama setelah mereka lulus. Responden yang menyatakan memperoleh pekerjaan lebih dari satu tahun hanya $8 \%$. Perolehan informasi kerja paling banyak berasal dari media cetak dan internet yaitu masing-masing sebesar 38\% dan 27\%. Responden yang mengisi kuisioner telah bekerja dan terserap oleh pasar kerja sebagai PNS (69\%) dan karyawan swasta (27\%). Mayoritas lulusan menduduki jabatan sebagai staf/karyawan pada sektor pemerintahan (91\%) sisanya pada swasta dalam negeri dan BUMN dengan jabatan sebagai manajer. Sebagian besar responden yaitu sebanyak 57\% menyatakan bahwa kemampuan akuntansi (81\%) dan penguasaan Teknologi dan Informasi (IT) menjadi faktor utama yang dipertimbangkan dalam memperoleh pekerjaan, selain kemampuan interpersonal dan kemampuan manajerial. Dari aspek penghasilan atau pendapatan yang diperoleh lulusan menyatakan bahwa lulusan mendapatkan gaji antara 1-5 juta per bulan sampai dengan 6-10 juta per bulan. Meskipun sebagian besar lulusan (52\%) menyatakan kesesuaian antara kompetensi yang dimiliki lulusan dengan kemampuan pengguna, namun sebagian lulusan $(47 \%)$ menyatakan masih memerlukan peningkatan kompetensi lanjutan untuk mendukung pekerjaan mereka seperti peningkatan keterampilan tingkat lanjut dan pelatihan akuntansi dan keuangan terbaru. Sebesar 54\% responden menyatakan bahwa keberadaaan dan peran lulusan masih dibutuhkan dalam masyarakat, dan kebutuhan lulusan dengan kompetensi dan keahlian akuntansi masih diperlukan (55\%) menunjukkan kecenderungan kebutuhan yang meningkat dalam masyarakat.

Tabel 1. Indikator Outcome

\begin{tabular}{ll}
\hline Deskripsi & Indikator \\
\hline Bentuk adaptasi dan transisi & Waktu tunggu pencarian kerja pertama kali \\
lulusan dari dunia pendidikan & Proses mendapatkan kerja (sebelum/setelah lulus) \\
tinggi ke dunia kerja & Perolehan informasi pekerjaan \\
& Peran relasi dalam perolehan pekerjaan \\
& Kesesuaian bidang studi dengan Pekerjaan \\
& Alasan mendapatkan pekerjaan pertama \\
& Alasan tidak bekerja/melanjutkan studi \\
& Alasan Berwirausaha \\
& Jenis Perusahaan/Institusi tempat bekerja (swasta, BUMN, Pemerintahan) \\
& Bidang Pekerjaan \\
& Jabatan \\
& Penghasilan yang diperoleh \\
& Jenis Pekerjaan \\
& Kondisi Pekerjaan \\
& Pengembangan karir lulusan \\
\hline
\end{tabular}

Sumber: Data Tracer Study (2020) 
Outcome bagi lulusan yang berwirausaha menunjukkan informasi bahwa pendapatan terbesar lulusan (80\%) yang bekerja sebagai wirausaha adalah 1-5 juta per bulan. Waktu yang dibutuhkan oleh lulusan untuk menyiapkan usaha wirausaha paling lama adalah satu tahun, meskipun ada lulusan yang mampu menyiapkan usaha mandiri dalam waktu antara 1-3 bulan (20\%). Lulusan yang bekerja sebagai wirausaha menyatakan terinspirasi saat perkuliahan dan termotivasi untuk membuka lapangan kerja (40\%). Sebagian besar responden (60\%) menyatakan bahwa kompetensi yang mereka miliki sesuai dengan kegiatan wirausaha yang mereka lakukan. Dalam bekerja sebagai wirausaha, lulusan menyatakan bahwa kompetensi akuntansi dan keuangan serta kemampuan kerja lapangan dan tim dibutuhkan dalam berwirausaha (40\%) sedangkan sisanya adalah kemampuan manajerial (20\%). Sebagian besar responden (80\%) menyatakan bahwa kemampuan analisis dan riset pasar yang diperoleh saat studi sangat mendukung usaha wirausaha yang dilakukan, sedangkan lainnya sebesar $40 \%$ adalah kemampuan akuntansi dan keuangan serta kemampuan manajerial.

Output lulusan berkaitan dengan penilaian diri terhadap penguasaan dan pemerolehan kompetensi yang dimiliki oleh lulusan dievaluasi berdasarkan indikator output sebagaimana disajikan pada tabel 2 berikut ini:

Tabel 2. Indikator Output

\begin{tabular}{ll}
\hline Deskripsi & Indikator Output \\
\hline Penilaian diri terhadap & Pemenuhan capaian pembelajaran yang diperoleh lulusan \\
penguasaan dan & IPK lulusan \\
pemerolehan kompetensi & Prestasi lulusan di bidang akademik \\
& Prestasi lulusan di bidang non akademik \\
& Masa studi \\
& Kelulusan tepat waktu \\
Keberhasilan studi/predikat kelulusan & Ketrampilan yang dimiliki \\
Motivasi & Nilai yang diperoleh/IPK Lulusan \\
Tingkat penguasaan kompetensi & Tingkat kontribusi prodi \\
& Peran kompetensi yang dimiliki terhadap penguasaan pekerjaan \\
& Kriteria pemerolehan kerja \\
& Kemampuan bahasa asing \\
Kemampuan penggelolaan IT \\
Pelatihan yang diikuti selama kuliah
\end{tabular}

Sumber: Data Tracer Study (2020)

Sebagian besar lulusan atau sebanyak 51\% menyatakan bahwa kompetensi yang dimiliki lulusan telah sesuai dengan pekerjaan (51\%), bahkan 27\% lulusan menyatakan sangat sesuai dengan pekerjaan. Sebanyak 63\% lulusan yang ditracer menyatakan bahwa kesesuaian ilmu (63\%) dan kemampuan penguasaan Teknologi dan Informasi (IT) merupakan hal utama yang dipertimbangkan oleh perusahaan/instansi dalam menerima pegawai baru, sedangkan hal lainnya seperti prestasi akademik dan kemampuan akuntansi dan keuangan dan syarat IPK di atas 3 dalam skala 4 menjadi faktor penunjang yang dipertimbangkan oleh perusahaan/instansi. Faktor pendorong kepuasan kerja lulusan 
paling dominan adalah kesempatan karir (40\%) serta gaji dan kesempatan studi dengan persentase masing-masing sebesar 19\%. Semua responden (100\%) menyatakan bahwa pengetahuan akuntansi dan bidang keuangan yang relevan adalah kompetensi yang mereka dapatkan dalam studi. Hal lain yang mereka dapatkan adalah berkaitan kemampuan interpersonal (61\%) dan kemampuan manajerial (52\%) serta kemampuan riset (48\%). Mayoritas responden lulusan menyatakan bahwa kompetensi yang dimiliki sesuai dalam menunjang penguasaan pekerjaan, bahkan responden sebanyak $31 \%$ menyatakan sangat sesuai. Bagi lulusan yang bekerja sebagai wirausaha kemampuan penguasaan IT menjadi faktor dominan yang dibutuhkan untuk mendukung pekerjaan $(60 \%)$, dan lainnya adalah kesesuaian ilmu (40\%) untuk mendukung pekerjaan yang mereka tekuni sebagai wirausaha. Fleksibilitas waktu (60\%) dan kesempatan kerja mandiri (40\%) menjadi faktor pendorong kepuasan kerja bagi lulusan yang bekerja sebagai wirausaha. Semua responden yang bekerja sebagai wirausaha menyatakan bahwa kemampuan analisis dan riset yang mereka dapatkan dalam studi, selain faktor dominan lainnya seperti kemampuan wirausaha (80\%) dan pengetahuan akuntansi dan bidang keuangan yang relevan (60\%) serta kemampuan manajerial (40\%) dan kemampuan interpersonal $(20 \%)$ diperlukan untuk untuk menunjang penguasaan pekerjaan sebagai wirausaha.

Indikator evaluasi proses pembelajaran dan kontribusi pendidikan tinggi terhadap pemerolehan kompetensi disajikan pada tabel 3 berikut ini.

Tabel 3. Indikator Proses Pembelajaran

\begin{tabular}{ll}
\hline Deskripsi & Indikator \\
\hline Evaluasi proses pembelajaran dan & Kesesuaian Kurikulum \\
kontribusi pendidikan tinggi terhadap & Karakteristik Proses pembelajaran \\
pemerolehan kompetensi & Rencana Proses Pembelajaran \\
& Pelaksanaan Proses Pembelajaran \\
& Metode Pembelajaran \\
& Monitoring dan Evaluasi Proses Belajar Mengajar \\
& Penilaian Pembelajaran \\
& Peningkatan Academic Athmosphere: \\
& Keterlibatan mahasiswa dalam kegiatan penelitian dan \\
& pengabdian masyarakat \\
& Kualitas Tenaga Pengajar \\
& Fasilitas Belajar Mengajar \\
& Kepuasan mahasiswa terhadap proses pembelajaran dan \\
& upaya tindak lanjut \\
\hline
\end{tabular}

Sumber: Data Tracer Study (2020)

Berkaitan dengan indikator proses pembelajaran, lebih dari 50\% menyatakan adanya kesesuaian ilmu yang mereka pelajari selama studi dengan pekerjaan mereka. Bahkan sebanyak $28 \%$ responden lainnya menyatakan ilmu yang mereka dapatkan sangat sesuai dengan pekerjaan yang ditekuninya, sedangkan sisanya 13\% menyatakan cukup sesuai. Lebih dari $60 \%$ responden menyatakan bahwa kualitas tenaga pengajar, metode pengajaran dan fasilitas pembelajaran sesuai untuk menunjang peningkatan keilmuan dan kemampuan. Hal yang sejalan juga dinyatakan oleh lulusan yang bekerja sebagai wirausaha, bahwa metode, kualitas tenaga pengajar dan proses pembelajaran yang mereka dapatkan saat studi 
sesuai untuk mendukung pekerjaan. Namun demikian, hampir semua lulusan juga memberikan masukan agar program studi lebih banyak lagi membangun atmosfer akademik seperti kegiatan kuliah tamu, bedah buku, seminar ilmiah, dan keterlibatan mahasiswa dalam penelitian dan pengabdian dosen diperlukan untuk menunjang fasilitas pembelajaran. Hal lainnya seperti ketersediaan ruang baca, pusat data pasar modal, survey kepuasan mahasiswa dan upaya tindak lanjut menurut lulusan dapat menunjang kesesuaian fasilitas pembelajaran.

Tracer study ini juga menggali persepsi kepuasan dari pengguna lulusan terhadap kinerja lulusan sebagaimana disajikan pada tabel 4. Dari jumlah pengguna lulusan sebagian besar berasal dari instansi pemerintah daerah/pusat yaitu sebanyak $60 \%$, sedangkan sisanya berasal dari perusahaan milik pemerintah (BUMN) dan lembaga pendidikan swasta masing-masing sebesar 20\%. Berdasarkan hasil tabulasi terhadap kepuasan pengguna diukur dari aspek integritas (etika dan moral), keahlian berdasarkan bidang ilmu (profesional), keluasan wawasan antar disiplin bidang ilmu, kepemimpinan, kerjasama tim, kemampuan Bahasa Inggris, kemampuan berkomunikasi dan kemampuan pengembangan diri. Dari aspek integritas, mayoritas pengguna lulusan menyatakan bahwa konsistensi, kejujuran, disiplin dan kepatuhan terhadap etika dan norma yang berlaku adalah faktor penting integritas yang dibutuhkan. Mayoritas pengguna lulusan (80\%) memberikan penilaian yang baik kinerja lulusan dalam aspek terhadap kemampuan dalam berperilaku etika dan moral, keahlian dalam bidang ilmu serta kemampuan kreativitas dan inisiatif. Lebih dari $60 \%$ responden pengguna lulusan juga memberikan penilaian kinerja yang baik terhadap lulusan berkaitan dengan kemampuan penggunaan IT, kemampuan berpikir kritis, kemampuan kerjasama dalam tim, kemampuan pengembangan diri serta kemampuan manajerial dan kepemimpinan. Penilaian secara keseluruhan oleh $60 \%$ pengguna lulusan menyatakan tingkat kepuasan yang baik terhadap kinerja lulusan. Secara umum, penilaian pengguna lulusan menyatakan bahwa lulusan memiliki kualifikasi yang diharapkan oleh pengguna seperti berperilaku etika dan moral, memiliki keahlian dalam bidang ilmu serta memiliki kreativitas dan inisiatif. Faktor lain yang mendukung kepuasan dari pengguna lulusan adalah kemampuan yang dimiliki lulusan dalam penggunaan IT, berpikir kritis, kerjasama dalam tim maupun kemampuan pengembangan diri.

Tabel 4. Indikator Kepuasan Pengguna Lulusan

\begin{tabular}{ll}
\hline \multicolumn{1}{c}{ Deskripsi } & \multicolumn{1}{c}{ Indikator } \\
\hline Evaluasi tingkat kepuasan pengguna & Integritas (etika dan moral) \\
terhadap keahlian/pengetahuan dan & Keahlian pada bidang ilmu (kompetensi utama/profesionalisme) \\
kompetensi yang dimiliki lulusan & Kemampuan berkomunikasi dalam bahasa asing \\
& Kemampuan penggunaan Teknologi Informasi \\
& Kemampuan berpikir kritis \\
& Kerjasama dalam tim \\
& Pengembangan diri \\
& Kreativitas dan inisiatif \\
& Kemampuan bekerja mandiri/kemandirian \\
& Kemampuan manajerial \\
& Etos kerja dan kedisiplinan \\
& Loyalitas dan komitmen \\
\hline
\end{tabular}

Sumber: Data Tracer Study (2020) 
Melalui hasil penelitian tracer study ini dapat memberikan informasi untuk peningkatan pengelolaan proses akademik, pembelajaran dan evaluasi kurikulum secara berkala sehingga dapat meningkatkan kompetensi yang dimiliki oleh lulusan dalam menunjang pekerjaan serta memenuhi harapan dari pengguna lulusan dan kebutuhan pasar kerja. Penyediaan kualifikasi tenaga pengajar yang relevan bidang ilmu dan penggunaan tenaga praktisi, memperbarui kurikulum dengan perkembangan isu-isu dan praktik akuntansi terkini dalam bidang akuntansi serta memperkaya muatan praktik dalam proses pembelajaran menjadi rekomendasi yang perlu ditindaklanjuti. Untuk meningkatkan keterkaitan perguruan tinggi dengan dunia usaha atau sektor pemerintahan disarankan membuka lebih banyak peluang untuk riset yg melibatkan lulusan yang bekerja pada institusi pemerintah dan swasta sehingga terjalin link and match antara perguruan tinggi dengan dunia kerja. Untuk meningkatkan jejaring alumni (networking) perlu dilakukan komunikasi yang intensif diantara alumni melalui pertemuan secara berkala dalam bentuk alumni gathering sehingga lulusan/alumni dapat berperan dan berkontrinusi lebih banyak dalam memberikan kontribusi bagi pengembangan Program Studi Magister Akuntansi Universitas Mataram di masa-masa mendatang.

\section{Kesimpulan, Implikasi dan Keterbatasan}

Hasil tracer study ini menjelaskan tentang masa transisi lulusan ke dunia kerja (outcome), penguasaan dan pemerolehan kompetensi lulusan (output) dan evaluasi proses pembelajaran terhadap pemrolehan kompetensi serta kepuasan pengguna lulusan terhadap keahlian dan kompetensi yang dimiliki lulusan serta kemampuan adaptasi lulusan dalam dunia kerja. Outcome lulusan menjelaskan bahwa lulusan terserap bekerja pada sektor pemerintahan dan sektor swasta dengan dengan posisi jabatan sebagai staff/karyawan dan tingkatan manajer menengah maupun bekerja sebagai berwirausaha. Kemampuan akuntansi dan penguasaan penggunaan teknologi informasi serta kemampuan manajerial menjadi kompetensi utama yang dibutuhkan untuk memperoleh pekerjaan. Peran lulusan dalam masyarakat dinilai baik dan kebutuhan lulusan dengan kompetensi akuntansi masih menunjukkan kecenderungan peningkatan pada pasar kerja. Output lulusan menunjukkan bahwa kompetensi yang dimiliki lulusan sesuai dengan pekerjaan, seperti kemampuan akuntansi dan bidang keuangan yang relevan serta kemampuan analisis dan riset dapat menunjang penguasaan pekerjaan. Penilaian responden lulusan terhadap proses pembelajaran menyatakan bahwa metode pembelajaran, kualifikasi tenaga pengajar dan fasilitas pembelajaran telah sesuai untuk mendukung peningkatan pengetahuan dan kemampuan yang diperlukan dalam menunjang pekerjaan. Tracer study ini juga mengungkapkan penilaian yang baik dari pengguna lulusan terhadap kualifikasi keahlian dan kompetensi yang dimiliki lulusan. Di masa mendatang, tingkat respon dari penelitian tracer study ini diharapkan dapat lebih meningkat dengan lebih banyak lagi lulusan dan pengguna lulusan yang berpartisipasi melalui penggunaan kuisioner yang terstandarisasi dan penggunaan sistem informasi tracer study berbasis website. 


\section{Daftar Pustaka}

Diana, E. \& As'ad. (2017). Analisis dan perancangan sistem informasi tracer study berbasis web. MediaSisfo 11(3), 817-829.

Fajaryati, N., Priyanto., Sukardiyono, T. \& Utami, A.D.W (2015). Studi penelusuran (tracer Study) terhadap alumni Program Studi Pendidikan Teknik Informatika Jurusan Pendidikan Teknik Elektronika Fakultas Teknik Universitas Negeri Yogyakarta. Jurnal Electronics, Informatics, and Vocational Education (ELINVO) 1 (1), 44-48.

Handajani, L., Alamsyah \& Widiastuty, E. (2015). Tracer study pada program Magister Akuntansi Universitas Mataram untuk meningkatkan kompetensi lulusan sesuai harapan stakeholder dan kebutuhan pasar kerja. Laporan Pengabdian Kepada Masyarakat Universitas Mataram tahun 2015.

Herwantie, T.; L. Handajani., Hermanto \& M. Irwan. 2018. Tracer study terhadap alumni Program Studi Magister Akuntansi Universitas Mataram Untuk pengembangan kurikulum sesuai dengan kebutuhan dunia kerja. Laporan Pengabdian Kepada Masyarakat Universitas Mataram tahun 2018.

ITB Career Center. (2018). Tentang tracer study. https://tracer.itb.ac.id/id/tentang/tentangtracer-study diakses tanggal 25 maret 2018.

Indriasari, S. (2012). Sistem informasi berbasis web untuk membantu kegiatan tracer study Program Diploma Institut Pertanian Bogor. Jurnal Sains Terapan Edisi II Vol-2 (1), 84-102

Karyono, G. \& Hermanto, N. (2013). Rancang bangun sistem tracer study online pada STMIK Amikom Purwokerto. Seminar Nasional Teknologi Informasi dan Komunikasi Terapan. Semarang 16 November 2013 halaman 126-133.

Marisa, F.., Efendi, D.U. \& Mumpuni, I.D. (2016). Tracer study system portal-based social network to optimize data collection on higher eduaction graduates. 2nd International Conferences on Information Technology and Business (ICITB) October 15th, 19-24.

Nursubiyantoro, E. \& Puryani. (2016). Perancangan sistem penelusuran alumni (Tracer study) berbasis web. Jurnal Optimasi Sistem Industri 9 (2), 85-92.

Schomburg, Harald. (2011). Methodology and methods of tracer studies. International Centre for Higher Education Research (INCHER-Kassel) University Kassel. Germany.

Rachmatullah, S. \& Gunawan, I. (2016). Aplikasi tracer study Universitas Madura. Jurnal Insand Comtech 1 (2), 31-37.

Renny, R. C., Ruhama, S. \& Sarjono, M.W. (2013). Exploring tracer study service in career center web site of Indonesia higher education. International Journal of Computer Science and Information Security 11(3), 36-39. 
Suryani, K. \& Kahirudin. (2017). Tracer study online pada Universitas Bung Hatta. Jurnal Edik Informatika 2 (1), 16-24.

Syam, A., \& Manga, A.R. (2017). Sistem tracer study alumni Fakultas Ilmu Komputer Universitas Muslim Indonesia menggunakan metode online analytical processing (OLAP). ILKOM Jurnal Ilmiah 9 (1), 86-90. 